Archived version from NCDOCKS Institutional Repository http://libres.uncg.edu/ir/asu/

\title{
Appalachỉan
}

B O O NE, NORTH CAROLINA

\section{Preventing Wrongful Convictions: An Analysis Of State Investigation Reforms}

\author{
By: Robert J. Norris, Catherine L. Bonventre, Allison D. \\ Redlich, James R. Acker, and Carmen Lowe
}

\begin{abstract}
As more innocents are exonerated and researchers learn more about the causes of wrongful convictions, criminal justice practices have been altered to reduce the number of erroneous convictions, although reforms have varied widely in scope and substance throughout the nation. In this article, we provide an analysis of state-level investigative reforms important to the production of wrongful convictions as of mid- 2016. Specifically, we collect and describe reform efforts in three investigatory areas: eyewitness identification, forensics, and interrogations. We then discuss wrongful conviction reforms and the innocence movement more generally, focusing on the importance of continued research into wrongful convictions as a critical policy issue in criminal justice.
\end{abstract}

Robert J. Norris, Catherine L. Bonventre, Allison D. Redlich, James R. Acker, and Carmen Lowe (2017) "Preventing Wrongful Convictions: An Analysis Of State Investigation Reforms" Criminal Justice Policy Review pp 1-30 Version Of Record Available At www.journals.sagepub.com 
The distinguished jurist Learned Hand once said that the wrongful conviction of an innocent person is "an unreal dream" (U.S. v. Garsson, 1923). This belief that the criminal justice system is infallible or, at the very least, errs with such infrequency that it warrants little attention or concern remained persistent throughout much of the 20th century. Over the past two decades, however, there has been a major shift in perception. Due in large part to the "innocence movement" and efforts to free innocent prisoners, educate the public, and reform justice systems, we now know that miscarriages of justice occur with some frequency. As these errors have been uncovered, we have learned a great deal about how our justice system can and does go awry, and, consequently, what can be done to prevent future wrongful convictions.

The lessons learned from exonerations have led to calls for changes in systems of criminal justice, and there are indications that innocence reforms have begun to reach public policy agendas (Norris, 2012; Zalman, 2006; Zalman \& Marion, 2014). Although many scholars have studied cases of wrongful convictions and the factors that lead to them (e.g., Garrett, 2011; Scheck, Neufeld, \& Dwyer, 2003), relatively few in the social science community have focused on the policy side of wrongful convictions. When policy reforms are addressed, they almost unexceptionally address discrete problem areas, but it is important to canvass multiple dimensions of innocence-related reforms in a more comprehensive fashion (Leo \& Gould, 2009).

In this article, we update and build upon an earlier article, which summarized state policies related to the prevention of wrongful convictions (Norris, Bonventre, Redlich, \& Acker, 2011). In particular, we examine three state policies which many researchers have identified as contributing to miscarriages of justice, and analyze reform efforts which therefore are likely to help reduce the incidence of wrongful convictions: eyewitness identification, forensics, and interrogations and confessions. Although other policies and practices have been linked to wrongful convictions, we limit our focus to these three areas because each concerns law enforcement investigations, where the process of wrongful conviction frequently originates when an innocent suspect is erroneously identified (see Zalman \& Larson, forthcoming). Furthermore, eyewitness identification procedures, forensic practices and testimony, and interrogation procedures have been studied extensively, resulting in widely accepted policy recommendations. Finally, each of these areas has been prioritized for reform by advocacy organizations such as the Innocence Project.

Our primary goal is to identify binding statewide policy initiatives in these areas, whether imposed by legislation, judicial decision, or otherwise, although where appropriate, we also address reform efforts adopted locally and at the federal level. Our secondary but equally important goal is to position this discussion within the context of the innocence movement and encourage scholars to analyze and evaluate policy reforms designed to prevent wrongful convictions, rather than focusing narrowly on specific cases. The compilation of initiatives provided here offers a benchmark against which to assess jurisdiction-specific reform efforts, which should be useful to help stimulate researchers, practitioners, and policymakers in their respective efforts to investigate, guard against, and correct wrongful convictions.

We begin with a general overview of wrongful convictions, including what is known about their prevalence and the factors contributing to their occurrence. We then discuss relevant research and suggestions for reform in the areas identified aboveeyewitness identification, forensics, and interrogation practices - and explain whether 
and how states have addressed the associated problems. We conclude with a call for increased scholarly attention to the policy dimensions of innocence-related justice systems reforms.

\section{Overview of Wrongful Convictions}

Although it is impossible to know with certainty how often innocent people are convicted, scholars have relied on various methods to estimate their prevalence. An early survey of criminal justice practitioners from Ohio, including state attorneys general and police, judges, and lawyers, reported that the respondents believed that less than $5 \%$, and more likely less than $1 \%$, of criminal convictions are erroneous (Huff, Rattner, \& Sagarin, 1986). Risinger (2007) examined the cases of defendants sentenced to death for rape-murder between 1982 and 1989, and estimated the factual error rate in such cases to be between $3.3 \%$ and $5 \%$. In what is perhaps the most empirically grounded estimate of error in death-penalty cases, a report published by the National Academy of Sciences conservatively estimated that $4.1 \%$ of those sentenced to death between 1973 and 2004 may be innocent (Gross, O'Brien, Hu, \& Kennedy, 2014).

Despite uncertainty about the true rate of wrongful convictions, more is known about exonerations or those cases in which the erroneous conviction of innocent persons has been detected and reversed. In all likelihood, these cases represent only "the tip of the iceberg of a much more deeply flawed justice system" (Feld, 2012, p. 244). That is, these known exonerations almost certainly do not represent all wrongful convictions since 1989 but instead are a relatively small, unrepresentative sample of miscarriages of justice that happened to be discovered and overturned. The Innocence Project, which tracks only exonerations secured through postconviction deoxyribonucleic acid (DNA) testing, lists 347 innocents who have been exonerated since 1989 (as of December 2016) on the basis of DNA evidence. The National Registry of Exonerations, which tracks both DNA and non-DNA exonerations since 1989, identifies 1,934 cases as of December 2016.

Although exonerations are an incomplete and likely unrepresentative sample of cases of the wrongful conviction of innocent defendants, they provide a window into where and how the criminal justice system can malfunction, from investigation through the adjudication process. They reveal that errors can occur both at trial and via plea bargaining, and that a number of factors are common correlates of and contributors to wrongful convictions. This "canonical list" (Gross, 2008, p. 186) includes eyewitness misidentification, forensic science issues (including errors, misconduct, shifted science, and discredited techniques), false confessions, unreliable snitches and informants, government misconduct, and poor defense lawyering. More nuanced analyses have helped distinguish between factors which are causal and those which tend to co-occur with wrongful convictions (Gould, Carrano, Leo, \& Hail-Jares, 2014). Furthermore, there are likely deeper "root causes" (Leo, 2005, p. 213) that have yet to be unearthed. For example, Lofquist (2014) suggested that justice system errors are tied to wider social, cultural, and political developments, and scholars seeking a deeper 
understanding of wrongful convictions should look to broader issues such as mass imprisonment, the "Southern Strategy," and the war on drugs (see also Laqueur, Rushin, \& Simon, 2014). Najdowski's $(2011,2014)$ research suggests that cultural stereotypes about race may create a pipeline for the wrongful convictions of African Americans by affecting the behaviors of both law enforcement officials and citizens. Some have even argued that the adversary system itself is conducive to and may even help produce wrongful convictions (Vidmar \& Coleman, 2014; Zalman, 2008).

These broader causes of wrongful convictions remain cloudy, and the majority of innocence scholarship, advocacy, and policy reform remain focused on the "canonical list" described above. Thus, although several factors are likely to contribute to wrongful convictions, we collected and present information about three investigative practices that have spawned relatively clear and well-established policy recommendations: eyewitness identification, forensic science, and police interrogation. We began by consulting information made available by advocacy organizations such as the Innocence Project, professional organizations like the National Association of Criminal Defense Lawyers (NACDL), state criminal justice agency websites, news reports, and previously published research. We also consulted statutes, court decisions, and other official directives. Where appropriate, we compared the identified policy reforms with best practices recommended by scholars, advocates, and national research organizations (e.g., the National Institute of Justice [NIJ] and the National Research Council). To the best of our knowledge, all policies are current as of mid-2016.

\section{Eyewitness Identification}

Eyewitness errors are among the leading factors contributing to wrongful convictions. The Innocence Project reports that misidentification was a factor in 235 of the first 325 DNA exonerations (72.3\%). In the National Registry of Exonerations database, mistaken identifications played a role in 579 of 1,934 exonerations (29.9\%), including 203 of $294(69 \%)$ sexual assault cases.

The fallibility of eyewitnesses is not a newly discovered phenomenon. Munsterberg (1908) wrote in the early 20th century about the unreliability of eyewitnesses and how they can affect trial outcomes, and psychologists have devoted significant time and resources to studying eyewitness-related issues since the 1970s (see Smalarz \& Wells, 2015). Among the topics considered have been the particular vulnerabilities and potential unreliability of certain types of eyewitnesses (particularly children); false memories; information processing, retention, and recall; and the effects of feedback given to witnesses during and following identification procedures. Two general categories of factors can influence the reliability of identifications: system variables and estimator variables. System variables "are (or potentially can be) under the direct control of the criminal justice system" (Wells, 1978, p. 1548) and include the actual identification procedures used, including personnel, instructions, type of lineup, and construction of the lineup. In contrast, estimator variables include the characteristics of the witness (such as age, race, eyesight) or of the situation (such as lighting, distance, presence or absence of a weapon) over which the system has no control. 
These issues have been studied extensively, and in the late 1990s, the American Psychology-Law Society assembled a group of researchers to review the scientific evidence on eyewitness procedures and issue a "white paper" with recommendations for best practices (Wells et al., 1998). Many of their recommendations were adopted by the NIJ when the NIJ formulated eyewitness identification procedure guidelines for law enforcement agencies in 1999. Psychological research has since continued, and findings regarding witnesses' perceptions, understanding, judgment, and decision making have led to a series of recommended reforms designed to enhance reliable identification procedures, and hence reduce the risk of erroneous arrests and convictions.

\section{Witness Instructions}

When participating in an identification procedure, witnesses may assume that the actual perpetrator is present in the lineup or photo array, and thus feel obliged to make an identification. Providing witnesses with specific instructions may help counter this potentially erroneous assumption. Thus, it is recommended that witnesses be told that the true perpetrator may or may not be displayed, and that they should not feel compelled to make an identification. Research has found that witnesses are less likely to select the wrong person when given this instruction (N. M. Steblay, 1997). In addition, the National Research Council (2014) and the Innocence Project suggest that witnesses should be told that the investigation will continue whether or not they make an identification.

As discussed below, law enforcement officers' conduct during an identification procedure can have important consequences. To prevent problems associated with officer feedback, witnesses also should be instructed that the attending officer does not know the identity of the actual suspect, or as the Innocence Project (n.d.-a) suggests, that they should "not look to the administrator for guidance.". Finally, the NIJ (1999) has suggested telling witnesses that "it is just as important to clear innocent persons from suspicion as to identify guilty parties" (p. 32).

\section{Blind Procedures}

The officer(s) conducting the identification procedure can influence witnesses in various ways. In many situations, the officer administering the lineup or photo array is involved in the case and consequently is aware of the suspect's identity. This officer then interacts with the witness before, during, and after the procedure. There is a risk that administrators will knowingly or unknowingly provide verbal or visual cues that can affect how witnesses approach the lineup, their expectations, the decisions they make, and their degree of confidence in their decisions (e.g., Harris \& Rosenthal, 1985; N. M. Steblay, 1997; N. K. Steblay, Wells, \& Douglass, 2014; Wells et al., 1998).

To avoid such complications, experts and advocates, including the Innocence Project and the National Research Council (2014), have recommended that the police use blind or double-blind lineup procedures, meaning that the officer administering 
the lineup does not know who the suspect is and thus cannot provide confirming or disconfirming feedback (Wells et al., 1998). Experimental studies have consistently shown that cues are often provided that do influence witnesses' behavior, and that a blind procedure is a straightforward way of reducing the transmission of such cues (see N. K. Steblay, Dysart, \& Wells, 2011).

\section{Confidence Statements}

One important element of a witness's identification is the degree of confidence he or she displays, which in turn is likely to influence the weight the police and a judge or jury places on the identification. The measure of confidence a witness expresses in his or her identification may be significantly influenced by what happens after a decision is made, including any feedback offered by the officer (Wells \& Bradfield, 1998). In addition to blind procedures, it is commonly suggested that a record should be made of the witness's confidence immediately following the identification and before any feedback is provided (National Research Council, 2014). Doing so creates a contemporaneous record of the witness's confidence and allows the fact finder to evaluate any changes in expressed confidence between the initial identification and trial.

\section{Lineup and Photo Array Composition}

How a lineup or photo array is constructed can significantly influence the outcome of an identification procedure. It therefore is suggested that displays be composed "in such a manner that the suspect does not unduly stand out" (NIJ, 1999, p. 29). In particular, the fillers - the displayed individuals other than the true suspect-ideally should be consistent with the witness's description of the offender and also should resemble the suspect. Different identification procedures should be used for each witness in cases involving multiple witnesses, and the suspect should be placed in different positions in a lineup or photo array to help guard against potential biases (Wells et al., 1998).

Although there is no set, agreed-upon number of lineup members or photos used in an array, the NIJ (1999) recommends a minimum of four fillers for live lineups and five fillers for photo spreads. However, absent necessity, there is virtually unanimous agreement that a live multiparty lineup or a photo array is preferable to a "show-up," in which a single suspect is presented to the witness. Not surprisingly, research confirms that show-ups are suggestive and increase the likelihood of a misidentification (Dekle, Beal, Elliott, \& Huneycutt, 1996; Wells et al., 1998; Yarmey, Yarmey, \& Yarmey, 1996).

\section{Sequential Presentation}

When witnesses are confronted with multiple subjects or photographs in a group, or simultaneously, and are asked to make an identification, they tend to make an identification by relying on "relative judgment." That is, witnesses will often try to determine 
which among the group most closely resembles their memory of the perpetrator and make an identification accordingly. This process is in contrast to making an "absolute judgment," wherein the witness determines whether a subject, displayed individually, matches his or her recollection of the offender (Wells et al., 1998). When subjects are presented simultaneously as a group, "there will always be someone who looks more like the culprit" than the others, who risks being identified for that reason alone (Wells et al., 1998, p. 10). Consequently, some evidence suggests that using "simultaneous" lineups or photo arrays increases erroneous identifications and, in particular, enhances the risk of false positives or misidentifying an innocent person (N. K. Steblay et al., 2011).

As a result, some have suggested using "sequential" presentations in lineups and photo arrays, where each subject is presented to the witness one at a time and the witness is asked whether he or she can make an identification. Sequential presentations encourage witnesses to rely on absolute rather than comparative or relative judgments. This reform was not formally recommended by Wells and colleagues (1998), although they discuss the potential benefits of such a practice, nor is it affirmatively endorsed by the Innocence Project (n.d.-a), the National Research Council (2014), or the NIJ (1999), although the NIJ report provides best practices for both sequential and simultaneous lineups. This lack of an official recommendation is largely based on the debate surrounding the potential for the sequential lineup procedure to negatively affect accurate identifications, and in particular of increasing the risk of false negatives, or a witness's failure to identify the true perpetrator (Clark, 2012; Wells, 2014).

\section{Recording}

As an additional reform, many have suggested video recording the identification process to create an objective record of what transpired. Wells et al. (1998) encouraged such a practice nearly 20 years ago, and it has been formally recommended by the Innocence Project (n.d.-a), the American Bar Association (2004), and the National Research Council (2014). The NIJ (1999) also recommends documenting lineup identifications by photo or video, and preserving witness statements by audio or video recording. However, according to a study done by the Police Executive Research Forum (2013), less than one third of law enforcement agencies video recorded eyewitness identification procedures.

\section{State Practices}

As shown in Table 1, 18 states have addressed eyewitness identification procedures in some way, but the adopted "reforms" vary in both scope and quality. All reforms resulted from legislation, with three exceptions: New Jersey (Attorney General directive), Oregon (Supreme Court decision), and Massachusetts (Supreme Judicial Court decision). Three states stopped short of mandatory alterations to police practices. Rhode Island created a task force that recommended reforms. The Massachusetts Supreme Judicial Court amended pretrial discovery rules to require prosecutors to 
Table I. State Eyewitness Reform.

\begin{tabular}{|c|c|c|c|c|c|c|c|}
\hline State & $\begin{array}{c}\text { Blind } \\
\text { administration }\end{array}$ & $\begin{array}{c}\text { Witness } \\
\text { instructions }\end{array}$ & $\begin{array}{c}\text { Lineup } \\
\text { composition }\end{array}$ & $\begin{array}{l}\text { Sequential } \\
\text { presentation }\end{array}$ & Feedback & $\begin{array}{l}\text { Witness } \\
\text { confidence }\end{array}$ & $\begin{array}{l}\text { Recording } \\
\text { procedures }\end{array}$ \\
\hline $\mathrm{CO}$ & $x$ & $x$ & $x$ & & & $x$ & \\
\hline CT & $x$ & $x$ & $x$ & $x$ & $x$ & $x$ & $x$ \\
\hline GA & $\mathrm{x}$ & $x$ & $x$ & & & $x$ & \\
\hline IL & $x$ & $x$ & $x$ & $x$ & $x$ & & $x$ \\
\hline KS & $X X$ & $X X$ & $X X$ & & & $X X$ & \\
\hline MD & & $x$ & $x$ & $x$ & $x$ & $x$ & $x$ \\
\hline MA & $x x$ & $X X$ & $X X$ & $X X$ & & $x x$ & $x x$ \\
\hline \multicolumn{8}{|l|}{$N V^{a}$} \\
\hline NJ & $x$ & $x$ & $x$ & $x$ & $x$ & $x$ & $x$ \\
\hline NC & $x$ & $X$ & $x$ & $x$ & $x$ & $x$ & $x$ \\
\hline $\mathrm{OH}$ & $x$ & $x$ & $x$ & & & $x$ & $x$ \\
\hline OR & $X X$ & $X X$ & $x X$ & $X X$ & $X X$ & $X X$ & \\
\hline RI & $X X$ & $X X$ & $X X$ & $X X$ & $X X$ & $X X$ & \\
\hline $\mathrm{TX}$ & $x$ & $x$ & $x$ & & & & $x$ \\
\hline $\mathrm{VT}$ & $x$ & $x$ & $x$ & & & $x$ & \\
\hline VA & $x X$ & $x X$ & $x x$ & $X X$ & $X X$ & $x X$ & $x x$ \\
\hline WV & $x$ & $x$ & $x$ & $x$ & $x$ & $x$ & $x$ \\
\hline WI & $x X$ & & & $X X$ & $X X$ & & $X X$ \\
\hline
\end{tabular}

Note. $X=$ required to some degree; $X X=$ recommended/preferred.

${ }^{a}$ Nevada requires departments to adopt written procedures for eyewitness identifications but does not specify what those procedures must include.

disclose information about identification procedures and any statements made by eyewitnesses (Fisher, 2008), and later created a task force that recommended that the Court pay attention to psychological knowledge about eyewitnesses and that practices be adapted accordingly. The Oregon Supreme Court expressed a preference that identifications follow scientific best practices rather than mandating changes, and established new rules for the admissibility of eyewitness identification evidence (State v. Lawson, 2012). ${ }^{1}$

The scope of mandatory reforms varies tremendously in the states that have adopted them. For example, in Wisconsin and Virginia, police departments are obliged to adopt written policies for conducting eyewitness procedures, but specific best practices are only recommended, rather than being required. A similar bill was recently signed by Kansas Governor Sam Brownback (Innocence Project, 2016). Nevada simply requires that written identification policies be adopted but does not specify what those policies should include.

The remaining states require one or more specific reforms, although only Connecticut, New Jersey, North Carolina, and West Virginia address all of the major issues identified by the scientific community: witness instructions, blind administration, lineup composition, sequential presentation, witness confidence statements, feedback, and recording. The remaining states - Colorado, Georgia, Illinois, Maryland, Ohio, Texas, and Vermont-address subsets of these issues. 
The comprehensiveness of state reforms varies with respect to the specific identification issues. For instance, North Carolina requires that eyewitnesses be instructed that the perpetrator may or may not be present, that the administrator does not know the suspect's identity, that witnesses should not feel compelled to make an identification, that it is as important to exclude innocents as it is to identify the perpetrator, and that the investigation will continue whether or not the witness makes an identification. Georgia, on the contrary, only requires that the witness be told that the suspect may or may not be present. Similar variability characterizes the requirements for lineup construction. For example, Connecticut has at least nine requirements, including specifying the number of fillers, instructions regarding multiple lineups, and rules pertaining to speech or gestures by lineup members. In contrast, Colorado only stipulates that fillers should be consistent with the witness's original description.

It also is worth noting that only six states - Colorado, Georgia, Illinois, North Carolina, Ohio, and Texas - explicitly address the consequences for failing to comply with the guidelines. In no state does noncompliance automatically preclude the admission of the eyewitness evidence. Rather, the norm is that the deviation may be considered in motions to suppress the evidence and may result in a cautionary jury instruction.

\section{Forensic Science Errors}

According to the National Registry of Exonerations, $23.5 \%$ of the first 1,934 cases ( $n=454$ as of December 2016) had "false or misleading forensic evidence" as a contributing factor (National Registry of Exonerations, n.d.). The Innocence Project (n.d.-b) notes that in "about half of DNA exonerations, unvalidated or improper forensic science contributed to the wrongful conviction." Scholars and practitioners have long been aware of forensic science evidence problems that could lead to wrongful convictions (see, for example, Giannelli, 1997; Peterson \& Leggett, 2007). Early proficiency testing programs showed unsatisfactory performance in many forensic disciplines in laboratories across the United States (Peterson \& Leggett, 2007). In addition, numerous incidents have been reported in which forensic analysts engaged in misconduct in the laboratory or provided misleading testimony that contributed to wrongful convictions (e.g., Cole, 2005; Giannelli, 1997; Hsu, 2012). When advocates began to use postconviction DNA testing to demonstrate the innocence of incarcerated individuals, analysis of those cases showed that forensic science evidence was a common correlate (Connors, Lundregan, Miller, \& McEwen, 1996). Garrett and Neufeld (2009) analyzed trial transcripts in DNA exoneration cases where forensic evidence was used at trial and found that $61 \%$ of the cases involved invalid forensic science testimony. Consequently, alongside awareness of these issues came demands for reform initiatives, including laboratory accreditation, quality assurance programs, examiner certification, and independent oversight of crime laboratories (Giannelli, 1997, 2007). For present purposes, we will focus on two of these mechanisms to ensure the validity and reliability of forensic science evidence in the criminal process: independent oversight of crime laboratories and accreditation of forensic science services. Although all of the suggested reforms are 
important, we concentrate on these two because these are areas in which states have made some progress. However, before discussing state reform efforts, it is worth examining relevant developments at the federal level.

\section{Federal Initiatives}

Nationally, crime laboratory scrutiny resulted in a 2009 National Research Council report ("NRC Report") that critically examined the state of forensic science practice in the United States. The report noted disparities in terms of quality, reliability, education, training, and funding, among others, and made 13 recommendations for improvement (National Research Council, 2009). One recommendation recognized a need for an independent federal agency to lead efforts to improve forensic science practice across the country, and thus proposed the development of a national entity to oversee forensic science practice. The report also called for mandatory laboratory accreditation (National Research Council, 2009). In response to the NRC Report, the U.S. Department of Justice established the National Commission on Forensic Science (NCFS) in 2013 to make national-level recommendations for strengthening forensic science practice (Department of Justice, 2015). The NCFS is comprised of stakeholders from all levels of government and includes forensic service providers, prosecutors, members of the legal profession, and law enforcement (Department of Justice, 2015). In addition, noting the role of forensic science in wrongful convictions, the President's Council of Advisors on Science and Technology (PCAST; 2016) recently issued a special report with recommendations regarding the uses of forensic science in criminal courts.

It is important to note that the NCFS is not the national governing body with the power to establish and enforce best practices for forensic science and standards for mandatory laboratory accreditation, as contemplated by the NRC Report (see National Research Council, 2009). Since its inception in 2013, the NCFS has made several recommendations to improve the reliability of forensic services. One recommendation calls for all forensic science service providers (FSSPs) at the federal, state, and local levels to become accredited (NCFS, 2015). Accreditation provides an independent recognition of a laboratory's adherence to industry standards. According to the NCFS (2015), "Universal accreditation will improve FSSP [sic] ongoing compliance with industry best practices, promote standardization, and improve the quality of services provided by FSSPs nationally" (p. 2). To encourage nonfederal laboratories to obtain accreditation, the NCFS recommendation proposes that the U.S. Attorney General requires the Department of Justice to provide grant funding only to nonfederal FSSPs who are accredited or undergoing the accreditation process.

The federal Congress also recognized the need for forensic science oversight. The Justice for All Act of 2004 (Pub. L. 108-405) required that crime laboratories that receive federal forensic science improvement grants certify the existence of an independent external government mechanism to investigate serious negligence or misconduct in the recipient laboratories. Although these federal developments are encouraging, it remains up to the states to provide independent oversight and accreditation of FSSPs. 


\section{State Practices}

Forensic science oversight commissions. Beyond the national level, 22 states have created commissions $^{2}$ to examine forensic science evidence issues or oversee crime laboratories (National Conference of State Legislatures, 2013a; Norris, Bonventre, Redlich, \& Acker, 2011). At the time of this writing, two of these commissions are no longer in operation: The California Crime Laboratory Review Task Force was ad hoc and concluded its business with a final report of findings and recommendations, and the statute enabling the Minnesota Forensic Laboratory Advisory Board was repealed by the state legislature because the board had inadvertently operated past its statutory expiration date (Dohman, 2013). The remaining 20 commissions are described in Table 2.

The majority of the commissions were created by statute $(n=19)$, two were established by state attorneys general, and one was created by a governor. The state oversight commissions vary in their membership, the scope of their functions, and regarding their authority over state forensic service providers (Norris et al., 2011). Some serve advisory roles, while others promulgate standards for the operation, accreditation, and certification of crime laboratories and their employees. Membership ranges so that some state commissions only include members with science, health, or forensic science credentials (e.g., District of Columbia Science Advisory Board, Maryland Forensic Laboratory Advisory Committee, North Carolina Forensic Science Advisory Board), while others involve members representing diverse criminal justice stakeholders such as prosecutors, defense attorneys, judges, and forensic scientists (e.g., Connecticut, Missouri, Texas).

The creation and assigned responsibilities of all of the forensic oversight commissions cannot be characterized as responses to wrongful convictions, per se. On one hand, some of the commissions were established before the innocence movement gained momentum and helped draw attention to the role of forensic science in wrongful convictions. For example, the Indiana Commission on Forensic Sciences and the Rhode Island Crime Laboratory Commission were founded in 1959 and 1978, respectively. On the other hand, most of those that were established after the advent of the innocence movement do not explicitly acknowledge wrongful convictions or forensic science errors or misconduct in their enabling legislation. This does not exclude the possibility that legislators' or governors' knowledge of wrongful convictions influenced the creation of such commissions, although it is difficult to be certain that it did. However, a few states enacted laws that can fairly be characterized as acknowledgments (either implicit or explicit) of the role that forensic science problems played in wrongful convictions.

The North Carolina Forensic Science Advisory Board and Office of the Ombudsman is an example of a commission that was created in response to a wrongful conviction. In 2010, Gregory Taylor was the first person exonerated by the North Carolina Innocence Inquiry Commission. Taylor served 17 years in prison for a murder conviction that was based, in part, on misleading forensic science testimony. Following Taylor's exoneration, the state Attorney General ordered an independent audit of the crime laboratory that had produced the misleading evidence (News Release, 2010). 


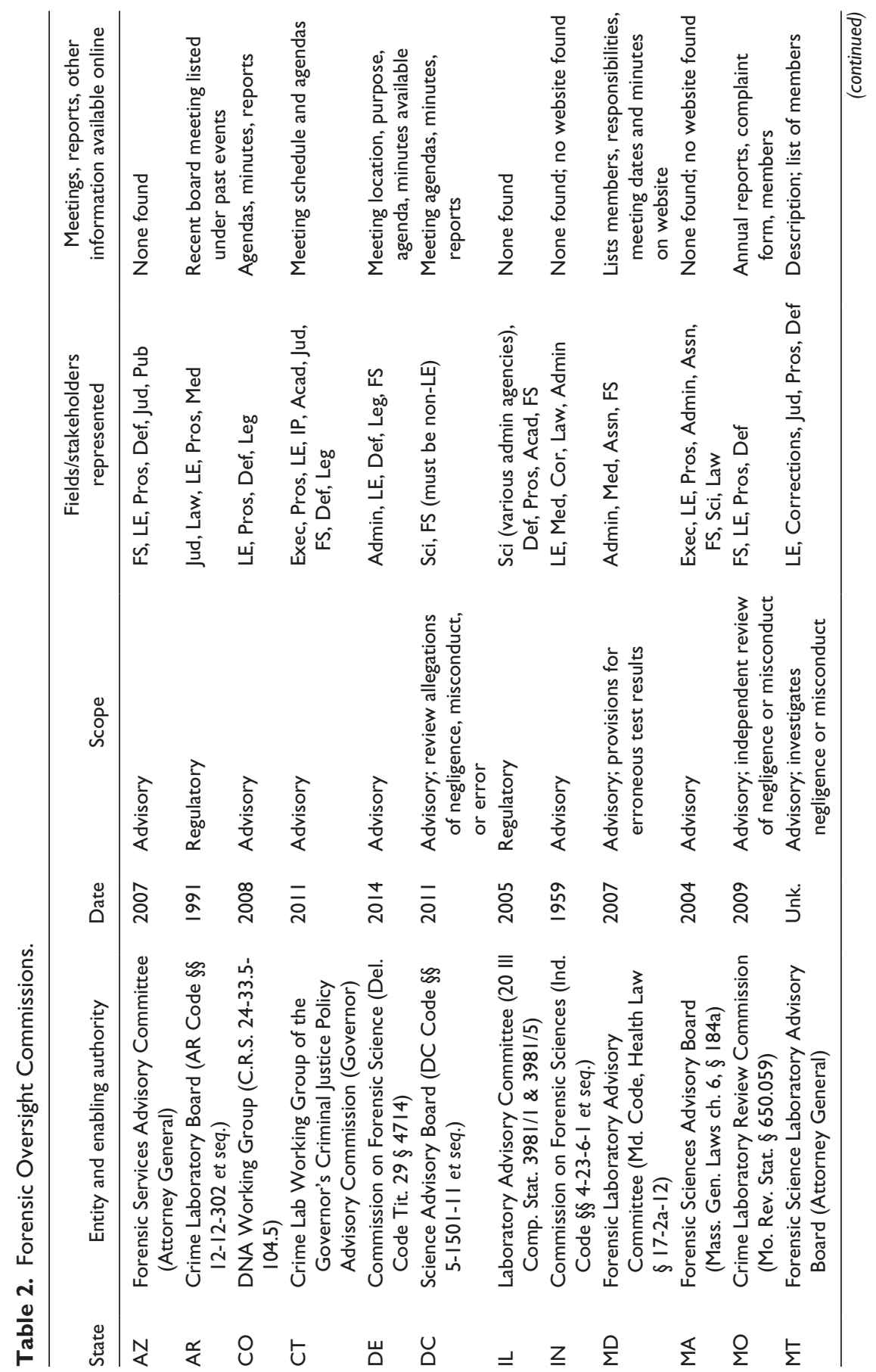




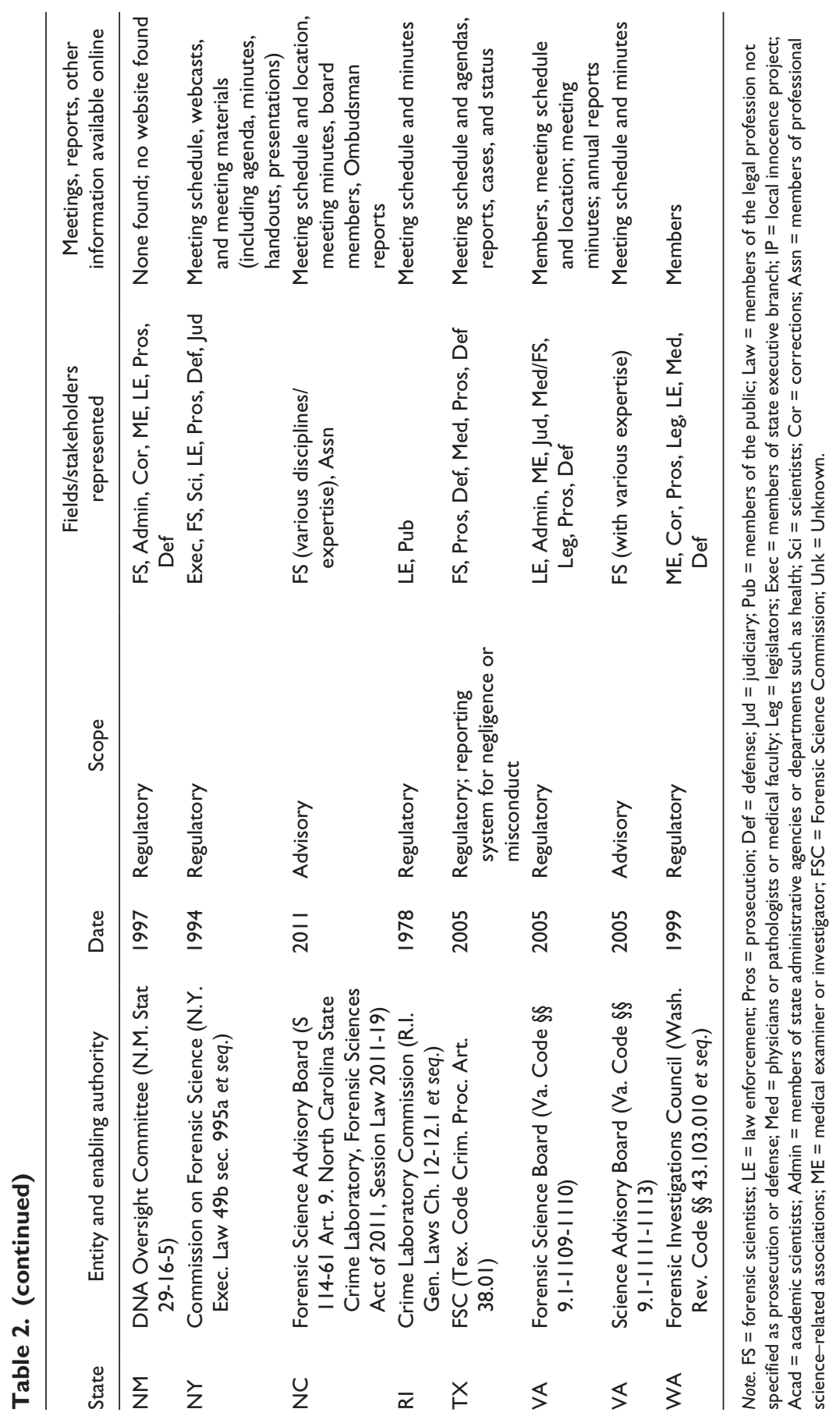


The audit revealed more than 200 cases in which analysts had issued misleading laboratory reports by omitting the results of negative or inconclusive serology tests (Swecker \& Wolf, 2010). One of the recommendations included in the audit report was for the state to develop a system for stakeholders, including prosecutors, defense attorneys, and the public, to report laboratory errors. According to the recommendation, "the objective of such a program would be the early identification and correction of errors and the identification of potentially flawed policies, practices and procedures" (Swecker \& Wolf, 2010, p. 30). Consequently, the state created the North Carolina Forensic Science Advisory Board and the Office of the Ombudsman. The preamble to the Forensic Sciences Act of 2011, which created these two entities, states that the aims of the Act are to

encourage efforts to eliminate sources of human error in forensic examinations, ... create the position of ombudsman to ensure that the best forensic processes and procedures are utilized in the state crime laboratory, . . . clarify the state's obligation to disclose to the defendant all information relating to the testing or examination of evidence and to penalize omission or misrepresentation relating to disclosure, and clarify that state crime laboratory personnel serve the public and the criminal justice system. (North Carolina Session Law 2011-19, H.B. 27)

Other commissions whose enabling statutes include the power to investigate allegations of professional misconduct or negligence have been established in the District of Columbia (DC Code 5-1501-11-12), Missouri (Mo. Rev. Stat. 650-059), and Texas (Tex. Code Crim. Proc. Art. 38.01). In addition, the Montana Forensic Science Laboratory Advisory Board, which was created by the Attorney General, indicates on its website that the Board has the power to investigate misconduct or negligence. ${ }^{3}$

Another important consideration is the extent to which these entities are transparent and thus enable concerned stakeholders or citizens to be aware of what efforts the commissions have undertaken to address crime laboratory problems. Thus, we examined whether each commission has a public website (or a webpage on a government website) and whether public meeting notices, meeting agendas, and minutes, reports, and any other relevant information about the work of the entity are provided on the site. Available information on the Internet about the commissions ranged from virtually nothing to dedicated websites complete with information about the commission, meetings, and reports (see Table 2). On the more comprehensive end of the range, the Texas Forensic Science Commission (FSC) website (http://www.fsc.texas.gov/) is exemplary. The FSC website provides information about meeting dates and agendas, licensing and accreditation, the status and disposition of complaints against forensic service providers in the state, and more.

Accreditation. Of the 409 publicly funded crime laboratories documented by the Bureau of Justice Statistics' (BJS) most recent census, 88\% overall are accredited and 99\% of state-level laboratories are accredited (Burch, Durose, Walsh, \& Tiry, 2016). Nevertheless, as listed below, only 12 jurisdictions currently mandate accreditation by law. 
Thus, forensic laboratory accreditation presently remains largely a voluntary affair. ${ }^{4}$ Although $88 \%$ is an impressive number that begs the question whether state accreditation laws are necessary, it is important to note that the BJS Census does not capture all FSSPs in the country such as those that are not located in laboratories (e.g., law enforcement fingerprint identification units; NCFS, 2015; National Research Council, 2009). It is estimated that many of these nonlaboratory FSSPs are not accredited (National Research Council, 2009).

The jurisdictions that require accreditation of at least some forensic disciplines are as follows: California, the District of Columbia, Hawaii, Indiana, Maryland, Minnesota, Missouri, Nebraska, New York, North Carolina, Oklahoma, and Texas. The laws that mandate accreditation vary in the scope of forensic science services covered, evidence admissibility, and enforcement mechanisms (see National Conference of State Legislatures, 2013b). For example, under the Minnesota statute, forensic laboratories in multiple disciplines (e.g., DNA, toxicology, latent prints, firearms, and more) may not operate after a specified date unless they are accredited (Minn. Stat. § 299C.157). On the contrary, the Indiana statute addresses only DNA laboratories and does not specify the consequences of noncompliance (Ind. Code § 10-13-6-14). Interestingly, although the state of Vermont does not appear to have a statute requiring accreditation per se, the Vermont Innocence Protection Act notes the state legislature's intent that the state crime laboratory "remain continuously accredited" (see 13 V.S.A. § 5561).

Given the recent developments at the federal level, it may be incumbent upon more states to develop oversight commissions and require service provider accreditation to ensure that the proposed national standards to improve forensic science practice are implemented.

\section{False Confessions}

Despite how counterintuitive it may seem that people would admit to crimes they did not commit, we know with certainty that suspects sometimes do falsely confess. Time and time again, false confessions are found to be one of the leading factors contributing to wrongful convictions. The Innocence Project reports that 88 of the first 325 DNA exonerations (27\%) involved a false confession or admission of guilt ${ }^{5}$; on the National Registry, 234 of the 1,934 (12.1\%) cases identified as of December 2016, including 173 of the $812(21.3 \%)$ criminal homicide cases, involved false confessions.

Like eyewitness errors, police interrogation tactics and suspects' confessions have been heavily studied in psychology. In a 2010 "white paper" reviewing relevant research, Kassin et al. (2010) discussed three types of false confessions: voluntary, compliant, and internalized. A voluntary false confession occurs when an innocent person confesses to a crime "without prompting or pressure from police," such as after the Lindbergh baby kidnapping, when 200 people claimed responsibility by "confessing" (Kassin et al., 2010, p. 14). Compliant false confessions, on the contrary, are direct reactions to interrogation techniques. "In these cases, the suspect acquiesces to the demand for a confession to escape a stressful situation, avoid punishment, or gain a promised or implied reward" (Kassin et al., 2010, p. 14). Finally, internalized false confessions involve suspects who not only admit guilt but who actually come "to 
believe that they may have committed the crime in question, sometimes confabulating false memories in the process" (Kassin et al., 2010, p. 15).

The reasons for false admissions of guilt vary, but they generally implicate situational and/or dispositional risk factors. Situational factors pertain to the circumstances of the interrogation that may induce a suspect to confess. Dispositional factors concern the suspect, including such matters as age, intellect, mental and physical health, and whether the individual being questioned is under the influence of drugs or alcohol (Kassin et al., 2010).

As recognized by the Supreme Court in Miranda v. Arizona (1966), modern-day interrogations are designed to be intense psychological experiences. Specifically, they are designed to overcome a suspect's resistance to admitting guilt, create a sense of hopelessness, and ultimately generate a confession. Thus, situational risk factors include isolating suspects from contact with others, controlling the interrogation environment, and the use of tactics such as presenting the suspect with false evidence of guilt and employing techniques of minimization (such as sympathizing with the suspect and offering excuses or justification for conduct) and maximization (such as by implying that a suspect who does not confess will suffer correspondingly harsh consequences) (Kassin et al., 2010).

In addition to the interrogation tactics that may generate false confessions, dispositional characteristics may make suspects more vulnerable. In particular, juveniles and those suffering from mental illness or intellectual disability are especially at risk, as evidenced by their overrepresentation among known false confessors (e.g., Kassin, 2008; Leo, 2009; Redlich, 2010). It has also been suggested that certain personality traits and disorders, such as depression and attention deficit hyperactivity disorder (ADHD), may be related to an increased vulnerability to interrogation tactics that can lead to false confessions (Gudjonsson, Sigurdsson, Asgeirsdottir, \& Sigfusdottir, 2006; Gudjonsson, Sigurdsson, Sigfusdottir, \& Young, 2012).

Although some experts have suggested changing the culture of American interrogations from accusatorial and confrontational to more investigative-style interviewing as is practiced in the United Kingdom (for a review, see Gudjonsson \& Pearse, 2011), another widely supported reform may help alleviate the problems that lead to false confessions: electronic recording of interrogations.

\section{Recording Custodial Interrogations}

In many ways, interrogations are secret affairs. They occur behind closed doors at police stations, insulated from scrutiny by the public and policymakers. To "lift the veil of secrecy" which surrounds the interrogation room, experts have recommended electronically recording custodial interrogations (Kassin et al., 2010, p. 25). There are numerous benefits to doing so. By creating an objective account of the process, recording protects both suspects and interrogators. Suspects may be protected from overly coercive tactics, as the recording may discourage investigators from using strategies that are questionable or impermissible. On the contrary, recording allows officers to focus on the suspect and his or her statements, rather than taking notes (Geller, 1998; 
Sullivan \& Vail, 2009), and also "protects the public's interest in honest and effective law enforcement, and the individual interests of those police officers wrongfully accused of improper tactics" (Stephan v. State, 1985, p. 1161). However, a survey of more than 600 North American law enforcement agents revealed that only $16 \%$ worked in agencies that required recording interrogations (either by audio or video), even though more than $80 \%$ of respondents believed that interrogation sessions should be recorded (Kassin et al., 2007).

Electronic recording is supported not only by many scholars but also by organizations such as the American Bar Association, New York County Lawyers' Association (2004); the International Chiefs of Police; and the NACDL and by law enforcement agencies, including the Federal Bureau of Investigation.

It is important that recordings are fair, accurate, and complete accounts of interrogation sessions. Thus, Kassin et al. (2010) advised that recordings should be made "with a camera angle that focuses equally on the suspect and interrogator" (p. 25), because a camera focused only on the suspect may result in biased evaluations of the confession (e.g., Lassiter, Geers, Handley, Weiland, \& Munhall, 2002; Lassiter, Slaw, Briggs, \& Scanlan, 2006). Furthermore, it is important that the entire interrogation session be recorded - not just the final statement - and that the recordings be preserved until appeals have been exhausted.

\section{State Practices}

Identifying state policies related to interrogation recording is somewhat challenging, but those we found are identified in Table 3. In at least 10 states, important stakeholders (e.g., appellate courts, attorneys general, police organizations, study commissions) have expressed a preference for and supported policies requiring the electronic recording of interrogations, but no formal binding policies have been adopted (see the farright column of Table 3). In 25 additional states and the District of Columbia, some type of binding policy has been implemented throughout the jurisdiction: 16 took the form of legislation, eight originated with state appellate courts (either through decisions, or rules of evidence or criminal procedure), one (Utah) is based in both a court decision and a statute, and in one state (Rhode Island) the state Police Accreditation Commission initiated the policy. As with eyewitness identification procedures, the nature and scope of these reforms vary widely.

In 20 of the 26 jurisdictions, the recording initiatives apply only to certain types of cases. The most common limitation is to restrict recording to felonies or some subset of them. For example, the Connecticut law applies to A- and B-level felonies, ${ }^{6}$ and Vermont's applies to felonies involving homicide or sexual assault. Other states, such as Illinois, Maryland, Missouri, and New Jersey, provide a specific list of crimes to which the recording policy applies, generally restricted to a specific set of serious felonies. Washington, D.C., policy applies only to violent crimes, and Maine requires departments to adopt procedures for recording interrogations of suspects suspected of "serious crimes." Finally, three states - California, North Carolina, and Wisconsin - require juvenile interrogations to be recorded, although in California the requirement only applies to juveniles suspected of murder. 
Table 3. State Interrogation Recording Policies.

\begin{tabular}{|c|c|c|c|c|c|c|}
\hline State & Required $^{\mathrm{a}}$ & $\begin{array}{l}\text { Limited } \\
\text { cases }\end{array}$ & $\begin{array}{l}\text { Length of } \\
\text { recording }\end{array}$ & Preservation & $\begin{array}{l}\text { Consequence for } \\
\text { noncompliance }\end{array}$ & $\begin{array}{l}\text { Recommended/ } \\
\text { preferred }\end{array}$ \\
\hline AK & $x$ & & $x$ & & $x$ & \\
\hline$A Z$ & & & & & & $x$ \\
\hline AR & $x$ & & & $x$ & $x$ & \\
\hline CA & $x$ & $x$ & $x$ & $x$ & $x$ & \\
\hline $\mathrm{CO}$ & & & & & & $x$ \\
\hline $\mathrm{CT}$ & $x$ & $x$ & & $x$ & $x$ & \\
\hline $\mathrm{DE}$ & & & & & & $x$ \\
\hline DC & $x$ & $x$ & $x$ & & $x$ & \\
\hline $\mathrm{FL}$ & & & & & & $x$ \\
\hline IL & $x$ & $x$ & & $x$ & $x$ & \\
\hline IN & $x$ & $x$ & & $x$ & $x$ & \\
\hline IA & & & & & & $x$ \\
\hline ME & $x$ & $x$ & & $x$ & & \\
\hline MD & $x$ & $x$ & & & & \\
\hline MA & $x$ & & & & $x$ & $x$ \\
\hline MI & $x$ & $x$ & $x$ & $x$ & $x$ & \\
\hline$M N$ & $x$ & & $x$ & & $x$ & \\
\hline MO & $x$ & $x$ & & & $x$ & \\
\hline MT & $x$ & $x$ & $x$ & $x$ & $x$ & \\
\hline NE & $x$ & $x$ & $x$ & & $x$ & \\
\hline $\mathrm{NH}$ & $x$ & & $x$ & & & \\
\hline $\mathrm{NJ}$ & $x$ & $x$ & $x$ & & $x$ & \\
\hline NM & $x$ & $x$ & $x$ & & & \\
\hline NY & & & & & & $x$ \\
\hline NC & $x$ & $x$ & $x$ & $x$ & $x$ & \\
\hline $\mathrm{OH}$ & $x$ & $x$ & & $x$ & & \\
\hline OK & & & & & & $x$ \\
\hline OR & $x$ & $x$ & $x$ & $x$ & $x$ & \\
\hline PA & & & & & & $x$ \\
\hline RI & $x$ & $x$ & $x$ & $x$ & $x$ & \\
\hline $\mathrm{TN}$ & & & & & & $x$ \\
\hline TX & $x$ & & $x$ & $x$ & $x$ & \\
\hline UT & $x$ & $x$ & & & $x$ & \\
\hline VT & $x$ & $x$ & $x$ & & $x$ & \\
\hline WV & & & & & & $x$ \\
\hline WI & $x$ & $x$ & & & $x$ & \\
\hline
\end{tabular}

Note. $\mathrm{X}=$ issue addressed in state initiative

aThe degree to which recording is actually required varies depending on the language used and the consequences of failing to comply, as discussed in the text. 
Another important limitation concerns specifying precisely what must be recorded, which is mentioned in 15 states (identified in Table 3 as "Length of Recording"). Eleven jurisdictions specify that the recording must include the advisement and waiver of constitutional rights (Miranda warnings), and another two require that the entire interrogation must be recorded. Two states limit what must be recorded. In New Hampshire, if the prosecution wishes to introduce a recording of an interrogation as evidence, the post-Miranda interrogation recording must be complete. Texas has a more complex statute that does or does not require the entire interrogation session to be recorded, depending on the circumstances: For adults, as long as the suspect received and waived his or her Miranda rights beforehand, written statements resulting from an unrecorded interrogation may be admitted, while oral statements generally are not, although there are exceptions; for juveniles, recording of complete interrogations is not required, but admission of statements is somewhat restricted (e.g., admissible if magistrate finds the juvenile understood his rights, if statements are made in open court, etc.).

In addition to specifying what is and is not required to be recorded, only 13 states mention the preservation of such recordings; seven states-Arkansas, California, Connecticut, Illinois, Montana, Oregon, and Texas - mention that the recording must be preserved until the conviction and appeals are final, or prosecution is barred by law; Ohio includes the first set of requirements but states that there is no need to preserve recordings if no charges are brought; and North Carolina requires recordings to be preserved until 1 year after the completion of all appeals. California adds that in juvenile cases, recordings must be preserved until the suspect is no longer under the jurisdiction of the juvenile court. In two states (Montana and Ohio), defendants may petition for an extended preservation. The remaining states mention preservation of recordings, but lack detail. The Rhode Island initiative says that agencies should preserve recordings in accordance with police department policy, and Maine requires police departments to adopt written policies, which must include a provision for the preservation of investigative records and notes. The policies in both Indiana and Michigan mention the preservation of recordings, but neither offers additional specifics.

The majority of states that have interrogation recording policies identify the consequences for the police's failure to comply. The sanctions vary, calling into question the extent to which recording is actually required in some states. Nine jurisdictions provide some type of inadmissibility sanction, so that statements from an unrecorded interrogation cannot be used against the defendant at trial unless a recognized exception is demonstrated: Alaska, Connecticut, the District of Columbia, Illinois, Indiana, Minnesota, ${ }^{7}$ Montana, Texas, ${ }^{8}$ and Utah. Most of these policies provide an opportunity for the state to demonstrate, either by a preponderance of the evidence or by clear and convincing evidence, that the statement was voluntary and/or that certain exceptions apply, such as recording not being feasible. Two of the states (Montana and Utah) allow the defendant to request a cautionary jury instruction in the event that an unrecorded statement is deemed admissible.

A number of states authorize less serious sanctions than excluding unrecorded statements from evidence. In four states-Arkansas, California, New Jersey, and 
North Carolina - the failure to record the interrogation may be considered relevant in determining the admissibility of a statement and/or to assessing claims of false or involuntary statements. California, New Jersey, and North Carolina also allow for cautionary jury instructions to be delivered on request. Such instructions, which advise the jury about the benefits of recording and/or warn jurors about the potential problems associated with not recording, are the only available sanction in six states: Massachusetts, Michigan, Nebraska, Oregon, Vermont, and Wisconsin.

A few states specify other consequences when the police inexcusably fail to record interrogations. In New Hampshire, for instance, an incomplete recording is not admissible, but "evidence gathered during the interrogation may still be admitted in alternative forms" (State v. Barnett, 2001, pp. 632-633). Missouri's statute allows the governor to withhold state funds from agencies that fail to comply and do not show good faith in attempting to do so. Rhode Island threatens noncompliant agencies with the loss of accreditation. Statutes in New Mexico and Ohio govern the recording of interrogations, although no clear consequences are dictated for noncompliance; the laws simply specify that failure to comply is not a basis for exclusion of the statement.

A few other provisions of related state policies are worth mentioning. For example, North Carolina and Vermont specify that the recording should show both the interrogator and the suspect. And at least three states-Michigan, Missouri, and Ohio - clarify that the failure to comply does not create a private cause of action for the defendant. Michigan's policy states that it should be considered a directive for law enforcement and that it does not confer any rights to the individual being interrogated. And finally, Ohio's law specifically states that an officer's failure to comply will not penalize the agency.

\section{Understanding and Contextualizing Innocence Reform}

Wrongful convictions are not a new phenomenon; in the United States, known miscarriages of justice date back at least to the erroneous murder convictions of Stephen and Jesse Boorn in the early 1800s (Warden, n.d.). Nor are the specific issues associated with wrongful convictions discussed here-eyewitness misidentification, scientific errors, and false admissions - new; Borchard (1932) identified these same factors as contributing to wrongful convictions more than 80 years ago. For the most part, however, not until fairly recently did these matters spark widespread concern among lawmakers and justice system officials. Some have suggested that the "age of innocence" is now upon us (e.g., Redlich \& Petrila, 2009; Zalman, 2011, p. 1499). As the innocence movement continues to mature, with more advocacy organizations focused on wrongful convictions and more legislative attention given to improving justice systems, it is vital that scholars expand the study of wrongful convictions to embrace policy initiatives.

Most states $(n=41)$ have addressed at least one of the three critical investigation stage issues known to influence the production of wrongful convictions, even if only with a recommendation or preference for reformed practices. Eight states have 


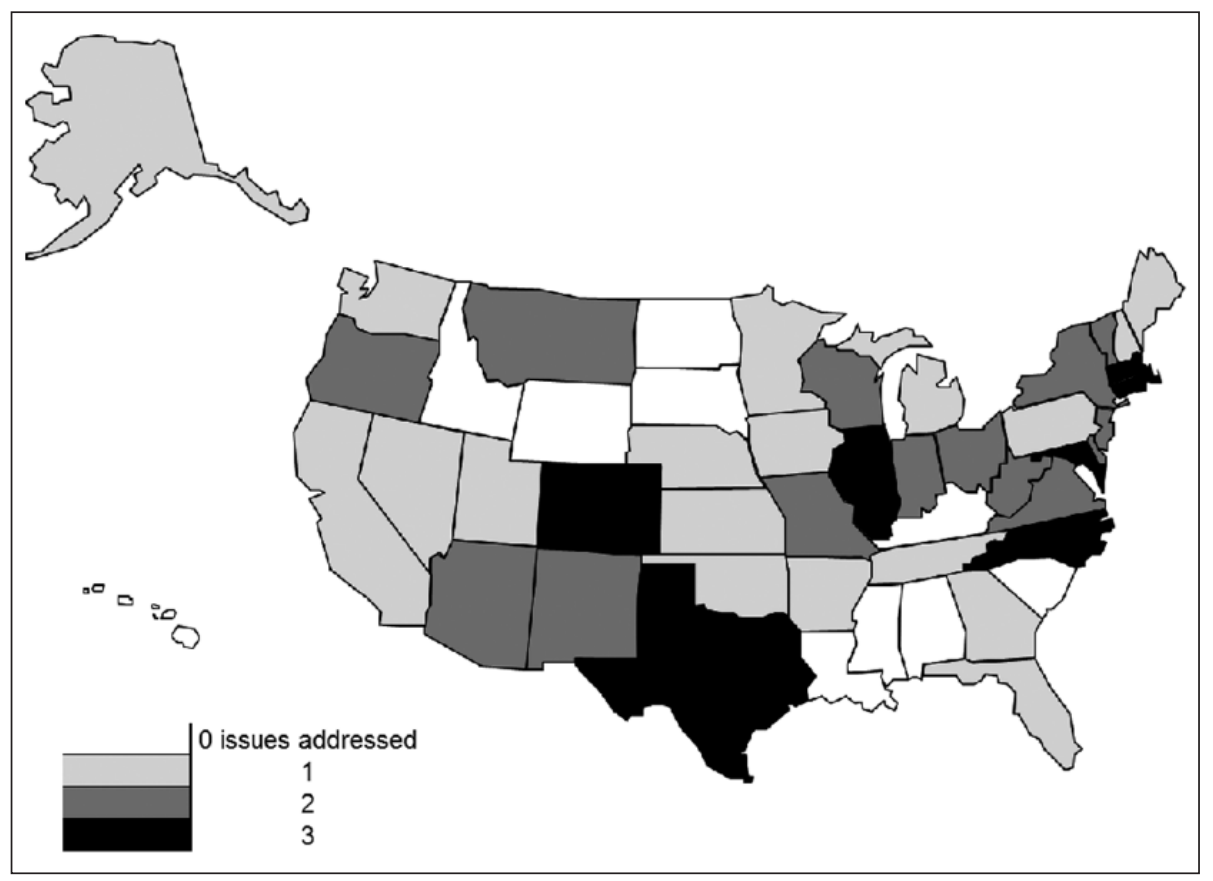

Figure I. Investigatory reforms across the United States.

addressed all three. The map in Figure 1 shows how many issues have been addressed in each state. The descriptive summary presented here and the depiction of investigatory reforms in Figure 1 are useful for criminal justice stakeholders and advocates, but they are equally important for the scholarly community.

Our hope is that researchers in a variety of fields - criminology and criminal justice, sociology, political science, and law, among others - will build on the portrait offered here to develop a fuller understanding of criminal justice policy reforms as they relate to wrongful convictions. In particular, areas that would benefit from theoretical and empirical study include the following: (a) the policy-formation process, (b) the implementation of specific reforms, and (c) evaluating the effectiveness of those reforms in reducing wrongful convictions.

Regarding the policy-formation process, more should be learned about why the laws discussed above were enacted. Indeed, a number of these reforms were not necessarily passed because of wrongful convictions or in reaction to exonerations, but they nevertheless have likely been useful to help alleviate errors of justice. Scholars can and should conduct in-depth analyses to help explain the variability displayed in the map shown above - in other words, to explain why some states have passed reforms relating to all three investigatory stages, while others have enacted none. A cursory glance suggests that it is not a purely geographic phenomenon, although there does appear to be some clustering of reform efforts in the Northeast and the Southwest that 
is worthy of further examination. It may be that these reforms are at least partially a result of policy diffusion, and scholars may draw on the classic diffusion of innovations framework (see Wejnert, 2002) to better understand the adoption and spread of innocence reforms over time. Furthermore, enacted reforms do not appear to be tied solely to the number of exonerations in a state. In the states that have addressed all three policy issues, the number of exonerations reported by the National Registry of Exonerations ranges from 5 (Colorado and Rhode Island) to 296 (Texas); on the contrary, states like California (166 exonerations) and Louisiana (46 exonerations) have addressed one and zero issues, respectively. It thus appears that a variety of factors can and do influence a state's decision to adopt, or fail to adopt, investigatory stage reforms. These issues are ripe for further investigation.

Kent and Carmichael (2015) have explored such issues, identifying the number of policies adopted in each state which correspond to the Innocence Project's model legislation issues, including DNA preservation laws, DNA access laws, eyewitness identification reforms, recording interrogations, and exoneree compensation statutes. They found that the dominant political party and the presence of Innocence Network organizations both affect the likelihood that a state will adopt policies designed to guard against or respond to wrongful convictions. Similarly, Owens and Griffiths (2012) explored states' passage of compensation statutes and reported that the number of exonerations in a state was the best predictor of whether a compensation law had been enacted, and that other political, social, and economic factors were less predictive. These analyses are intriguing, and the differing results suggest that further investigation is in order. For example, the factors that affect altering investigatory practicespreconviction policies that affect the day-to-day work of police officers such as those described here - might be fundamentally different from those which come into play to help produce compensation statutes - postconviction remedies designed to provide monetary relief and help rectify the difficulties associated with exoneree reintegration. In addition, scholars can profitably analyze outcomes other than the presence or absence of state policies by developing dependent measures of the quality of those laws, as Norris (2012) did with compensation statutes. Such analyses would not only highlight why states do and do not adopt reforms but would also unearth factors that influence the quality of those reforms. Similarly, historical and qualitative research could produce illuminating case studies focused on individual policies, comparing successes and failures, to provide a fuller understanding of policy processes, framing techniques, and the rhetoric involved in innocence reforms.

Researchers also can delve more deeply into how adopted reforms are implemented. For example, how do police departments train, supervise, and evaluate officers as they put eyewitness reforms into practice? What challenges do they face? What consequences, if any, do agencies experience for noncompliance? Do these matters vary between agencies or jurisdictions, and if so, why? These are important questions and we know little by way of answers.

In addition, significant evaluation research is necessary to better understand the effectiveness of the reforms suggested by academic experts and policy advocates. Although recommendations like the eyewitness identification measures outlined 
earlier and for recording interrogations have become common, we know relatively little about how effective these changes are in practice. For instance, it has been widely reported by psychologists that certain eyewitness reforms are likely to reduce mistaken identifications, but as Clark (2012) has pointed out, many of these same reforms have the potential to reduce accurate identifications as well. The lack of official recommendations regarding the adoption of sequential lineups, for example, likely owes largely to this debate, which has been concentrated within the psychological community (e.g., Clark, 2012; Wells, Steblay, \& Dysart, 2012). The countervailing views are based primarily on the results of laboratory studies where guilt and innocence are known with certainty, but evaluation research must continue to expand beyond experimental laboratories to the real world. Evaluations of police departments that have adopted various reforms should be conducted and replicated, not only with respect to eyewitness reforms (Wells, Steblay, \& Dysart, 2015) but to assess the effects of forensic oversight and recording interrogations as well.

Furthermore, assessment of the effects of policy reforms can take a broader approach to see whether state-level policy mandates have an impact on the number of wrongful convictions. For instance, in New Jersey, nearly half (nine out of 19) of the known wrongful convictions that occurred before the Attorney General's identification procedures mandate involved a mistaken eyewitness identification; since the mandate, only one of eight involved a misidentification. Similarly, in Illinois, 21.5\% (32 of 149 cases) of wrongful convictions before the state established their forensic oversight commission involved false or misleading forensic evidence, yet none of the 28 known wrongful convictions since has. Neither of these scenarios points to causality; we cannot say that the reforms were the cause for the decrease in that particular type of error. Furthermore, many of the reforms are too recent for meaningful analysis of their effects. And, as our ability to identify past convictions as wrongful increases, along with judges' and prosecutors' willingness to upend such cases, the direct efficacy of implemented reforms will remain elusive. Still, such research should be on the radars of innocence scholars. Both evaluations of individual reforms in specific agencies as well as long-term, jurisdiction-level studies of the effects of new policies can provide meaningful information for policymakers and practitioners. Fully informed policy discussions require broad knowledge about the full range of effects of presumably salutary policy reforms.

Our hope is that the descriptive analysis offered here will help identify and stimulate research into issues of importance in the evolving innocence movement. It is time to build on the described baseline of innocence-related investigatory reforms - which provides a snapshot of what exists - and direct increased scholarly attention to understanding the how and why of innocence reforms.

\section{Conclusion: The Past, Present, and Future of Innocence Reforms}

Wrongful convictions almost certainly date back to the inception of systems of justice. Although some early legislation touched on related matters, such as Wisconsin's 1913 compensation statute, in contrast, most innocence-related reforms have occurred in the 
past 20 years and it appears unlikely that the political and cultural salience of innocence will abate in the near future. The National Registry of Exonerations reported 157 exonerations in 2015, more than in any other year. Accounts of questionable convictions continue to command public attention, as evidenced by the popularity of recent media programming such as the hit podcast, Serial, and the documentary series, Making a Murderer (e.g., Heese, 2016; Nyman, 2016; Woodruff, 2014). As more wrongful convictions come to light and more innocents are exonerated, the number of advocacy organizations dedicated to these issues also continues to grow. Approximately 70 organizations currently are members of the Innocence Network and many of them actively work to reform state and national justice systems. Indeed, the present is a vital time for criminal justice reform efforts. Academic researchers must keep step with others addressing issues of innocence by expanding their studies to gain a deeper understanding of the policy dimensions of reform initiatives designed to help prevent and reduce the incidence of wrongful convictions.

\section{Declaration of Conflicting Interests}

The author(s) declared no potential conflicts of interest with respect to the research, authorship, and/or publication of this article.

\section{Funding}

The author(s) received no financial support for the research, authorship, and/or publication of this article.

\section{Notes}

1. Although a full discussion is beyond the scope of this article, it is worth noting that a growing number of states allow the admission of expert testimony at trial on the reliability of eyewitness identification evidence. For a full discussion and summary of state laws, see Vallas (2011).

2. Although the entities assume various names, such as committee, working group, council, or commission, we refer to them collectively as commissions.

3. We did not examine state administrative codes for this article. While an oversight commission may be created statutorily, administrative codes may outline the detailed rules and regulations of an agency's operation, including whether that agency has rule-making authority. These administrative codes are worthy of their own analysis, as they may address issues related to wrongful convictions.

4. It should be noted that accreditation in DNA is a prerequisite for DNA laboratories that participate in the National DNA Index System operated by the Federal Bureau of Investigation (FBI Laboratory, 2016).

5. It should be noted that this number is somewhat misleading, as the Innocence Project categorizes false confessions by case, rather than by the individual defendant. For example, if a case involved the wrongful convictions of four individuals, but only three actually confessed, they would all get counted as "false confessions or admissions" in the Innocence Project dataset. The actual percentage of DNA exonerees who falsely confessed is likely closer to $15 \%$.

6. The Connecticut law also applied to capital cases; however, the state repealed its capital punishment law in 2012. 
7. Minnesota threatens that the information may be suppressed if the violation is "substantial" (State v. Scales, 1994).

8. Texas does not apply the inadmissibility sanction if there is evidence suggesting that assertions made in the statement are found to be true.

\section{References}

American Bar Association. (2004). Report to the House of Delegates: Statement of best practices for promoting the accuracy of eyewitness identification procedures. Author.

American Bar Association, New York County Lawyers' Association. (2004). Report to the House of Delegates. Retrieved from http://www.americanbar.org/content/dam/aba/directories/policy/2004_my_8a.authcheckdam.pdf

Borchard, E. M. (1932). Convicting the innocent: Sixty-five actual errors of criminal justice. New Haven, CT: Yale University Press.

Burch, A. M., Durose, M. R., Walsh, K., \& Tiry, E. (2016). Publicly funded forensic crime laboratories: Quality assurance practices, 2014. Retrieved from http://www.bjs.gov/content/ $\mathrm{pub} / \mathrm{pdf} / \mathrm{pffclqap} 14 . \mathrm{pdf}$

Clark, S. E. (2012). Costs and benefits of eyewitness identification reform: Psychological science and public policy. Perspectives on Psychological Science, 7, 238-259.

Cole, S. A. (2005). More than zero: Accounting for error in latent fingerprint identification. Journal of Criminal Law and Criminology, 95, 985-1078.

Connors, E., Lundregan, T., Miller, N., \& McEwen, T. (1996). Convicted by juries, exonerated by science: Case studies in the use of DNA evidence to establish innocence after trial. Washington, DC: U.S. Department of Justice.

Dekle, D. J., Beal, C. R., Elliott, R., \& Huneycutt, D. (1996). Children as witnesses: A comparison of lineup versus showup identification methods. Applied Cognitive Psychology, $10,1-12$.

Department of Justice. (2015). National Commission on Forensic Science: Charter. Retrieved from https://www.justice.gov/ncfs

Dohman, R. L. (2013). Letter to Paul Thissen, Speaker of the House, Minnesota House of Representatives. Retrieved from http://www.commissions.leg.state.mn.us/lcpfp/advisory_ groups/2013/DPS_AdvisoryGroups.pdf

FBI Laboratory. (2016). National DNA Index System (NDIS) operational procedures manual. Retrieved from https://www.fbi.gov/file-repository/ndis-procedures-manual-ver4approved-04272016.pdf/view

Feld, B. C. (2012). Kids, cops, and confessions: Inside the interrogation room. New York: New York University Press.

Fisher, S. Z. (2008). Eyewitness identification reform in Massachusetts. Massachusetts Law Review, 91, 52-66.

Garrett, B. L. (2011). Convicting the innocent: Where criminal prosecutions go wrong. Cambridge, MA: Harvard University Press.

Garrett, B. L., \& Neufeld, P. J. (2009). Invalid forensic science testimony and wrongful convictions. Virginia Law Review, 95, 1-97.

Geller, W. A. (1998). Videotaping interrogations and confessions. In R. A. Leo \& G. C. Thomas III (Eds.), The Miranda debate: Law, justice and policing (pp. 303-313). Boston, MA: Northeastern University Press.

Giannelli, P. C. (1997). The abuse of scientific evidence in criminal cases: The need for independent crime laboratories. Virginia Journal of Social Policy \& the Law, 4, 439-478. 
Giannelli, P. C. (2007). Wrongful convictions and forensic science: The need to regulate crime labs. North Carolina Law Review, 86, 163-235.

Gould, J. B., Carrano, J., Leo, R. A., \& Hail-Jares, K. (2014). Predicting erroneous convictions. Iowa Law Review, 99, 471-522.

Gross, S. R. (2008). Convicting the innocent. Annual Review of Law and Social Science, 4, 173-192.

Gross, S. R., O’Brien, B., Hu, C., \& Kennedy, E. H. (2014). Rate of false conviction of criminal defendants who are sentenced to death. Proceedings of the National Academy of Sciences, $111,7230-7235$.

Gudjonsson, G. H., \& Pearse, J. (2011). Suspect interviews and false confessions. Current Directions in Psychological Science, 20, 33-37.

Gudjonsson, G. H., Sigurdsson, J. F., Asgeirsdottir, B. B., \& Sigfusdottir, I. D. (2006). Custodial interrogation, false confession and individual differences: A national study among Icelandic youth. Personality and Individual Differences, 41, 49-59.

Gudjonsson, G. H., Sigurdsson, J. F., Sigfusdottir, I. D., \& Young, S. (2012). False confessions to police and their relationship with conduct disorder, ADHD, and life adversity. Personality and Individual Differences, 52, 696-701.

Harris, M. J., \& Rosenthal, R. (1985). Mediation of interpersonal expectancy effects: 31 metaanalyses. Psychological Bulletin, 97, 363-386.

Heese, M. (2016, February 8). "Serial" takes the stand: How a podcast became a character in its own narrative. The Washington Post. Retrieved from https://www.washingtonpost.com/

Hsu, S. S. (2012, April 16). Convicted defendants left uninformed of forensic flaws found by Justice Dept. The Washington Post. Retrieved from https://www.washingtonpost.com/ local/crime/convicted-defendants-left-uninformed-of-forensic-flaws-found-by-justicedept/2012/04/16/gIQAWTcgMT_story.html?utm_term=.109cbd23dde6.

Huff, C. R., Rattner, A., Sagarin, E., \& MacNamara, D. E. (1986). Guilty until proved innocent: Wrongful conviction and public policy. Crime \& Delinquency, 32, 518-544.

Innocence Project. (n.d.-a). Eyewitness misidentification. Retrieved from http://www.innocence project.org/causes-wrongful-conviction/eyewitness-misidentification

Innocence Project. (n.d.-b). Unvalidated or improper forensic science. Retrieved from http:// www.innocenceproject.org/causes/unvalidated-or-improper-forensic-science/

Innocence Project. (2016). Kansas gov. Brownback signs law to prevent witness misidentification, top contributor to wrongful conviction. Retrieved from http://www.innocenceproject .org/kansas-governor-brownback-signs-law-legislation-aimed-preventing-witnessmisidentification-top-contributor-wrongful-conviction/.

Kassin, S. M. (2008). False confessions: Causes, consequences, and implications for reform. Current Directions in Psychological Science, 17, 249-253.

Kassin, S. M., Drizin, S. A., Grisso, T., Gudjonsson, G. H., Leo, R. A., \& Redlich, A. D. (2010). Police-induced confessions: Risk factors and recommendations. Law and Human Behavior, 34, 3-38.

Kassin, S. M., Leo, R. A., Meissner, C. A., Richman, K. D., Colwell, L. H., Leach, A.-M., \& Fon, D. L. (2007). Police interviewing and interrogation: A self-report survey of police practices and beliefs. Law and Human Behavior, 31, 381-400. doi:10.1007/s10979-0069073-5

Kent, S. L., \& Carmichael, J. T. (2015). Legislative responses to wrongful conviction: Do partisan principals and advocacy efforts influence state-level criminal justice policy? Social Science Research, 52, 147-160. 
Laqueur, H., Rushin, S., \& Simon, J. (2014). Wrongful convictions, policing, and the "wars on crime and drugs.” In A. D. Redlich, J. R. Acker, R. J. Norris, \& C. L. Bonventre (Eds.), Examining wrongful convictions: Stepping back, moving forward. (pp. 93-107). Durham, NC: Carolina Academic Press.

Lassiter, G. D., Geers, A. L., Handley, I. M., Weiland, P. E., \& Munhall, P. J. (2002). Videotaped interrogations and confessions: A simple change in camera perspective alters verdicts in simulated trials. Journal of Applied Psychology, 87, 867-874.

Lassiter, G. D., Slaw, R. D., Briggs, M. A., \& Scanlan, C. R. (2006). The potential for bias in videotaped confessions. Journal of Applied Social Psychology, 22, 1838-1851.

Leo, R. A. (2005). Rethinking the study of miscarriages of justice: Developing a criminology of wrongful conviction. Journal of Contemporary Criminal Justice, 21, 201-223.

Leo, R. A. (2009). False confessions: Causes, consequences, and implications. Journal of the American Academy of Psychiatry and the Law, 37, 332-343.

Leo, R. A., \& Gould, J. B. (2009). Studying wrongful convictions: Learning from social science. Ohio State Journal of Criminal Law, 7, 7-30.

Lofquist, W. S. (2014). Finding the causes in the contexts: Structural sources of wrongful convictions. In A. D. Redlich, J. R. Acker, R. J. Norris, \& C. L. Bonventre (Eds.), Examining wrongful convictions: Stepping back, moving forward. (pp. 19-33). Durham, NC: Carolina Academic Press.

Miranda v. Arizona, 384 U.S. 436 (1966).

Munsterberg, H. (1908). On the witness stand. New York, NY: McClure.

Najdowski, C. J. (2011). Stereotype threat in criminal interrogations: Why innocent black suspects are at risk for confessing falsely. Psychology, Public Policy, and Law, 17, 562-591.

Najdowski, C. J. (2014). Interactions between African Americans and police officers: How cultural stereotypes create a wrongful conviction pipeline for African Americans. In A. D. Redlich, J. R. Acker, R. J. Norris, \& C. L. Bonventre (Eds.), Examining wrongful convictions: Stepping back, moving forward. (pp. 55-70). Durham, NC: Carolina Academic Press.

National Commission on Forensic Science. (2015). Universal accreditation. Retrieved from https://www.justice.gov/ncfs/file/477851/download

National Conference of State Legislatures. (2013a). Legislative study and oversight of forensic services. Retrieved from http://www.ncsl.org/Documents/cj/ForensicOversightPanels.pdf.

National Conference of State Legislatures. (2013b). State accreditation offorensic laboratories. Retrieved from http://www.ncsl.org/Documents/cj/AccreditationOfForensicLaboratories .pdf

National Institute of Justice. (1999). Eyewitness evidence: A guide for law enforcement. Washington, DC: U.S. Department of Justice.

National Registry of Exonerations. (n.d.). Retrieved from http://www.law.umich.edu/special/ exoneration/Pages/about.aspx

National Research Council. (2009). Strengthening forensic science in the United States: A path forward. Washington, DC: National Academies Press.

National Research Council. (2014). Identifying the culprit: Assessing eyewitness identification. Washington, DC: National Academies Press.

News Release. (2010). AG Cooper orders outside review of state crime lab. Retrieved from http://ncdoj.gov/News-and-Alerts/News-Releases-and-Advisories/Press-Releases/ AG-Cooper-orders-outside-review-of-state-crime-lab.aspx

Norris, R. J. (2012). Assessing compensation statutes for the wrongly convicted. Criminal Justice Policy Review, 23, 352-374. 
Norris, R. J., Bonventre, C. L., Redlich, A. D., \& Acker, J. R. (2011). "Than that one innocent suffer": Evaluating state safeguards against wrongful convictions. Albany Law Review, 74, 1301-1364.

Nyman, S. (2016, January 14). Just how popular is "Making a Murderer"? Post-Crescent. Retrieved from http://www.postcrescent.com/story/news/local/2016/01/12/just-how-popular-makingmurderer/78507664/

Owens, M. L., \& Griffiths, E. (2012). Uneven reparations for wrongful convictions: Examining the state politics of statutory compensation legislation. Albany Law Review, $75,1283-1327$.

Peterson, J. L., \& Leggett, A. S. (2007). The evolution of forensic science: Progress amid the pitfalls. Stetson Law Review, 36, 621-660.

Police Executive Research Forum. (2013, March 8). A national survey of eyewitness identification procedures in law enforcement agencies (Final report submitted to the National Institute of Justice, Office of Justice Programs, U.S. Department of Justice). Retrieved from http://www.policeforum.org/assets/docs/Free_Online_Documents/ Eyewitness_Identification/a\%20national\%20survey\%20of\%20eyewitness\%20identification $\% 20$ procedures $\% 20 \mathrm{in} \% 201 \mathrm{aw} \% 20$ enforcement $\% 20$ agencies $\% 202013$.pdf.

President's Council of Advisors on Science and Technology. (2016). Report to the president forensic science in criminal courts: Ensuring scientific validity of feature-comparison methods. Retrieved from https://www.whitehouse.gov/sites/default/files/microsites/ostp/ PCAST/pcast_forensic_science_report_final.pdf

Redlich, A. D. (2010). The susceptibility of juveniles to false confessions and false guilty pleas. Rutgers Law Review, 62, 943-957.

Redlich, A. D., \& Petrila, J. (2009). Special issue: The age of innocence: Miscarriages of justice in the 21 st century. Behavioral Sciences \& the Law, 27, 297-489.

Risinger, D. M. (2007). Innocents convicted: An empirically justified factual wrongful conviction rate. Journal of Criminal Law and Criminology, 97, 761-806.

Scheck, B., Neufeld, P., \& Dwyer, J. (2003). Actual innocence: When justice goes wrong and how to make it right. New York, NY: New American Library.

Smalarz, L., \& Wells, G. L. (2015). Contamination of eyewitness self-reports and the mistaken identification problem. Current Directions in Psychological Science, 24, 120-124.

State v. Barnett, 789 A.2d 629 (2001).

State v. Lawson, 291 P.3d 673 (Or. 2012).

State v. Scales, 518 N.W.2d 587 (Minn. 1994).

Steblay, N. K., Dysart, J., \& Wells, G. L. (2011). Seventy-two tests of the sequential lineup superiority effect: A meta-analysis and policy discussion. Psychology, Public Policy, and Law, 17, 99-139.

Steblay, N. K., Wells, G. L., \& Douglass, A. B. (2014). The eyewitness post identification feedback effect 15 years later: Theoretical and policy implications. Psychology, Public Policy, and Law, 20, 1-18.

Steblay, N. M. (1997). Social influence in eyewitness recall: A meta-analytic review of lineup instruction effects. Law and Human Behavior, 21, 283-297.

Stephan v. State, 711P.2d 1156 (1985).

Sullivan, T. P., \& Vail, A. W. (2009). The consequences of law enforcement officials' failure to record custodial interviews as required by law. Journal of Criminal Law and Criminology, 99, 215-234.

Swecker, C., \& Wolf, M. (2010). An independent review of the SBI forensic laboratory. Retrieved from http://ncdoj.gov/getdoc/62b3af3e-aacc-4eb9-91a5-97c3d0cbea10/Independent-Reviewof-SBI-Forensic-LAB.aspx 
U.S. v. Garsson, 291 F. 646 (S.D.N.Y. 1923).

Vallas, G. (2011). A survey of federal and state standards for the admission of expert testimony on the reliability of eyewitnesses. American Journal of Criminal Law, 39, 97-146.

Vidmar, N., \& Coleman, J. E. (2014). The American adversary system: Sources of error in the criminal adjudication process. In A. D. Redlich, J. R. Acker, R. J. Norris, \& C. L. Bonventre (Eds.), Examining wrongful convictions: Stepping back, moving forward (pp. 141-156). Durham, NC: Carolina Academic Press.

Warden, R. (n.d.). First wrongful conviction: Jesse Boorn and Stephen Boorn. Retrieved from http://www.law.northwestern.edu/legalclinic/wrongfulconvictions/exonerations/vt/boornbrothers.html

Wejnert, B. (2002). Integrating models of diffusion of innovations: A conceptual framework. Annual Review of Sociology, 28, 297-326.

Wells, G. L. (1978). Applied eyewitness-testimony research: System variables and estimator variables. Journal of Personality and Social Psychology, 36, 1546-1557.

Wells, G. L. (2014). Eyewitness identification: Probative value, criterion shifts, and policy regarding the sequential lineup. Current Directions in Psychological Science, 23, 11-16.

Wells, G. L., \& Bradfield, A. L. (1998). “Good, you identified the suspect”: Feedback to eyewitnesses distorts their reports of the witnessing experience. Journal of Applied Psychology, 83, 360-376.

Wells, G. L., Small, M., Penrod, S., Malpass, R. S., Fulero, S. M., \& Brimacombe, C. A. E. (1998). Eyewitness identification procedures: Recommendations for lineups and photospreads. Law and Human Behavior, 22, 603-647.

Wells, G. L., Steblay, N. K., \& Dysart, J. E. (2012). Eyewitness identification reforms: Are suggestiveness-induced hits and guesses true hits? Perspectives on Psychological Science, 7, 264-271.

Wells, G. L., Steblay, N. K., \& Dysart, J. E. (2015). Double-blind photo lineups using actual eyewitnesses: An experimental test of a sequential versus simultaneous lineup procedure. Law and Human Behavior, 39, 1-14.

Woodruff, J. (2014, December 11). What "Serial"-mania says about the growing popularity of podcasts. PBS NewsHour. Retrieved from http://www.pbs.org/newshour/bb/serial-maniasays-growing-popularity-podcasts/.

Yarmey, A. D., Yarmey, M. J., \& Yarmey, A. L. (1996). Accuracy of eyewitness identifications in showups and lineups. Law and Human Behavior, 20, 459-477.

Zalman, M. (2006). Criminal justice system reform and wrongful conviction: A research agenda. Criminal Justice Policy Review, 17, 468-492.

Zalman, M. (2008). The adversary system and wrongful conviction. In C. R. Huff \& M. Killias (Eds.), Wrongful conviction: International perspectives on miscarriages of justice (pp.71-91). Philadelphia, PA: Temple University Press.

Zalman, M. (2011). An integrated justice model of wrongful convictions. Albany Law Review, $74,1465-1524$.

Zalman, M., \& Larson, M. (Forthcoming). Elephants in the station house: Serial crimes, wrongful convictions, and expanding wrongful conviction analysis to include police investigation. Albany Law Review, 79.

Zalman, M., \& Marion, N. E. (2014). The public policy process and innocence reform. In M. Zalman \& J. Carrano (Eds.), Wrongful conviction and criminal justice reform: Making justice (pp. 24-38). New York, NY: Routledge. 


\title{
Author Biographies
}

Robert J. Norris is an assistant professor in the Department of Government and Justice Studies at Appalachian State University. His research explores law and social change, miscarriages of justice, and decision-making in the criminal justice process. Dr. Norris has written extensively on various issues related to wrongful convictions and is author of the book, Exonerated: $A$ History of the Innocence Movement (NYU Press, 2017).

Catherine L. Bonventre, an assistant professor in the Department of Justice and Policy Studies at Guilford College, holds a JD, an MS in forensic biology, and a PhD in criminal justice. She is co-editor (with A. Redlich, J. Acker, and R. Norris) of the volume Examining Wrongful Convictions: Stepping Back, Moving Forward.

\begin{abstract}
Allison D. Redlich is a professor in the Department of Criminology, Law and Society at George Mason University. Her research focuses on miscarriages of justice, including wrongful convictions and the factors that lead to legal decisions that are not knowing, intelligent, and voluntary.

James R. Acker is a Distinguished Teaching Professor in the School of Criminal Justice, University at Albany. He received his JD. at Duke University and his $\mathrm{PhD}$ at the University at Albany. He is co-editor (with A. Redlich) of Wrongful Conviction: Law, Science, and Policy (Carolina Academic Press, 2011) and (with A. Redlich, R. Norris, and C. Bonventre) of Examining Wrongful Convictions: Stepping Back, Moving Forward (Carolina Academic Press, 2014). He has authored numerous articles addressing wrongful convictions, capital punishment, criminal law, criminal procedure, and related areas.
\end{abstract}

Carmen Lowe earned her MPA with a concentratiopn in administration of justice from the Department of Government and Justice Studies at Appalachian State University. 